\title{
Lithuanian carrot market: production, foreign trade, and price transmission issues
}

\section{Nelè Jurkènaitė ${ }^{1}$, Dimitrios Paparas ${ }^{2}$}

\section{1 - Lithuanian Institute of Agrarian Economics, Vilnius, Lithuania 2 - Harper Adams University, Shropshire, the United Kingdom}

\section{Keywords:}

Agriculture

Carrot

Price transmission

Supply chain

Trade

\section{Article history:}

Received 05.08.2018

Received in revised

form 24.11.2018

Accepted 28.03.2019

\section{Corresponding}

author:

Nelè Jurkènaitè

E-mail:

nele@laei.lt

DOI: $10.24263 / 2304-$

974X-2019-8-1-17

\section{Abstract}

Introduction. The paper aims to analyse the situation in Lithuanian carrot market and focus on the changes of agricultural production, structure of foreign trade, and vertical price transmission along the supply chain over the period of 2011-2017.

Materials and methods. Methods of comparative and graphical analysis of the main indicators of carrot production and foreign trade development rely on the secondary data of Statistics Lithuania. The research on the vertical price transmission along the supply chain of domestic carrots relies on price series collected by SE 'Agricultural Information and Rural Business Centre' and employs unit root tests, cointegration, causality and asymmetry tests.

Results and discussion. The conducted research evidences that over the analysed seven years carrot production in Lithuania has shrank. Harvested area dropped from 2,400 to 1,800 ha, while the harvest reduced by more than $1 / 3$. The key driving forces behind the negative development trends were prolonged unfavourable weather conditions and the Russian import ban of 2014. The transformation of the export structure took place during the unsuccessful harvesting years and contributed to the worsening of farmers' welfare.

The analysis of the farm-retail prices shows that the examined series are integrated of I(1). Thus, we found a significant structural break in April 2015, which has been included as a dummy variable in the cointegration approaches. The Engle-Granger cointegration test confirms the presence of the long-run relationship between the analysed price series. The Granger causality test shows that the causality is running from retail to farm prices. Finally, there is a strong evidence of symmetric price behaviour, i.e. positive and negative shocks are transmitted from retailers to farmers with the same intensity.

Conclusions. The study shows that the prolonged unfavourable weather conditions and the Russian import ban were among the main contributors determining price fluctuations on the Lithuanian carrot market in 2011-2017. The analysis of vertical price transmission of domestic carrots indicates that retailers may experience some market power. 


\section{Introduction}

In Lithuanian agriculture carrots remain an important vegetable, which has demand on domestic and foreign markets. Although over the last seven years carrots have represented almost the same share in the total harvested area of Lithuanian vegetables (in 2011 accounted for $16.44 \%$, in $2017-15.65 \%$ [30]), the changes in carrot production were more dramatic than the alteration of average indicators of the EU agriculture and witnessed the shrinking of the domestic production.

This research investigates carrot price as one of the factors which could contribute to market inefficiencies and encourage farmers to leave carrot production if they believe that their welfare is violated. Such behaviour is explained by cobweb theory arguing that production depends on the price during the previous period [28]. The paper also contributes to the academic literature which states that a traditional markup concept often does not explain price behaviour in the market, because we often observe the lagged or incomplete price transmission among the supply chain [16]. Conclusions on asymmetric price behaviour in the supply chains of agricultural commodities are common. The divergence from the markup concept to some extent could be explained by the theoretical model [11] investigating the changes in state-of-the-art of consumers' demand, marketing services or farm supply. However, it is argued that empirical research enrich our knowledge about price asymmetry [2], while most of the current theoretical models face limitations and cannot explain price behaviour properly.

According to previous academic studies, the dissonance with the markup concept could be explained by different factors affecting vertical or spatial price transmission and market efficiency. Some of these factors are commodity- or country-specific, while another could be used as an explanatory variable for a wider phenomenon. The main factors which influence price behaviour on the market of agricultural commodities are level of perishability [2, 4, 21, 22, 25, 27], market power and concentration related indicators [2, 4, 20, 21, 24, 25, 29], selected risk-management and pricing strategies [19, 20], imperfect information [20, 21, 24, 27] and search costs [4], adjustment or menu costs [4, 21, 24, 25], the shortage of stored commodities or speculation by the shortage $[14,18,20,24]$, the expectation of price change $[2,12]$, outbreaks of diseases related to agricultural production [22], trade restrictions [22, $25]$, interventions of policy makers [2, 24], annual and long-term climate changes $[14,22$, 29], seasonality [4, 29], the shortage of water resources [14], structural and economic crises [22], the presence of competitive proposals, including the substitution by imported products [20], and etc. The complexity of the phenomenon confirms the statement that each case of the price transmission in the supply chain is unique as the country of origin, industry, and the selected for the analysis time period make difference [2].

This statement is supported by many studies with contradicting results for different countries and supply chains. It should be noted that carrots as an object of price transmission research were selected only in a few studies [4, 6, 12, 15, 17, 24, 27], while the problems of vertical price transmission in the vegetable sector generated an impressively high number of publications (reviews on such studies are provided in [1, 3, 23, 24, 26]). The aforementioned studies on carrot price transmission investigate cases of the USA [6, 15, 27], Italy [24], the United Kingdom [17], Austria [17], Germany [12, 17], Ireland [17], and Hungary [4]. Most of the mentioned papers analyse the short- and long-term relationships between prices along the supply chain of carrots. These studies differ by number of stakeholders in the supply chain and employ various data frequency. Findings confirm both the asymmetric and symmetric price transmission along the supply chain of carrots, but the cases of the 
symmetric transmission are more often. The price leading supply chain stakeholders also differ.

However, three of the aforementioned studies select less common research directions. Two papers investigate the differences in behaviour of organic and conventional carrot prices in the USA and find the evidence of symmetric [15] and asymmetric behaviour [6]. These studies also show the different adjustment to the long-run equilibrium. Another paper estimates the impact of Euro introduction on vertical price transmission of carrots and concludes that there is no evidence of significant impact on changes of retail prices [12].

The paper aims to analyse the situation in the Lithuanian carrot market and focuses on the changes of agricultural production, structure of foreign trade, and vertical price transmission along the supply chain over the period of 2011-2017. The research contributes to the scientific discourse on vertical price transmission adding the case of Lithuanian domestic carrot supply chain, which has not attracted an in-depth analysis until now.

\section{Materials and methods}

In order to achieve the aim, the paper combines two subtasks and applies different research methods. The first subtask analyses the changes of domestic carrot production and the structure of foreign trade. The comparative and graphical analysis of the secondary data collected by Statistics Lithuania is conducted. The analysis identifies the most important aftermaths of these changes for the period from 2011 to 2017 and discusses the development of carrot price.

The second subtask investigates the vertical price transmission along the supply chain of carrots of Lithuanian origin on domestic market during the period from 2011 to 2017. This subtask relies on the prices derived from the secondary data collected by the SE 'Agricultural Information and Rural Business Centre'. The farm price is calculated as the average of minimum and maximum price of carrots on farms. The retail price shows the average price of seven Lithuanian counties for not prepacked carrots in the main network supermarkets. The weekly data is aggregated into monthly frequency using average values.

Monthly prices in Figure 1 demonstrate that both farm and retail prices experience twofold impact of seasonal changes. First, the early start of the harvesting season is characterized by the sharp increase in price level, while the nearing to the end of the season shows the decrease of prices. Second, the introduced price series advise of a remarkable success solving the problem of domestic carrot availability for the consumer throughout the year. An uninterrupted supply of domestic carrots at the retail level became available only after 2013. However, during the analysed period farm price series have repetitive gaps as the selling of the last year harvest on farm is done earlier than the early season carrots appear on the shelves of supermarkets.

The review of the literature on vertical price transmission in vegetable sector allowed to select econometric tests for the analysis of relationships between farm and retail prices. Thus, the judgement about the efficiency of the domestic supply chain and the functioning of carrot market could be done. First, the analysed price series are tested for the stationarity in order to select the appropriate research methods. The augmented Dickey-Fuller (ADF) test [7] is run to classify the price series as stationary or non-stationary. 


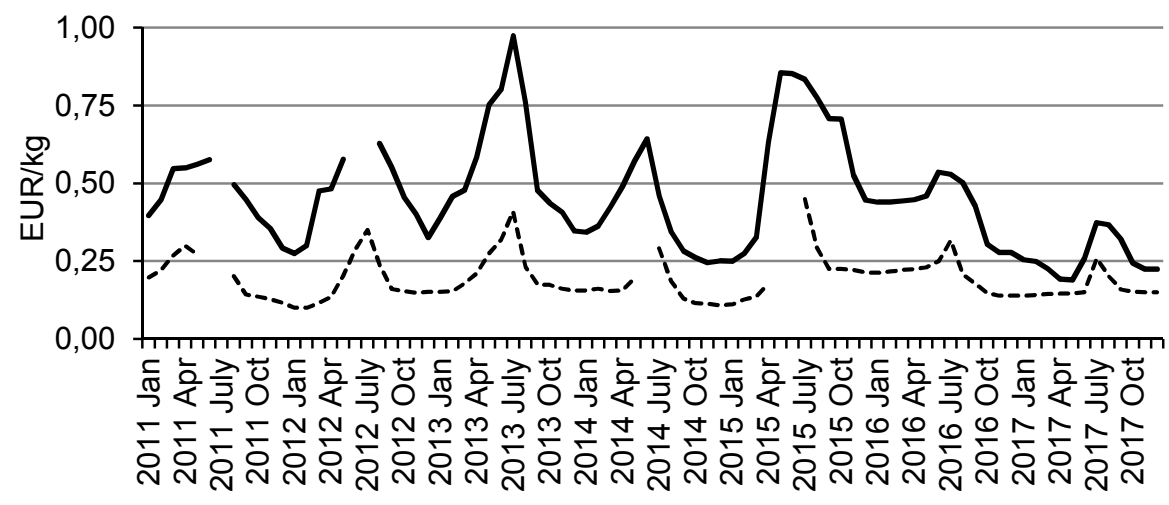

retail ------ farm

Figure 1. Average carrot prices: retail and farm levels

Source: own calculations on the basis of the data collected by SE 'Agricultural Information and Rural Business Centre'

The long-run relationship between two tested variables can be affected by the presence of structural breaks in the data. These possible breaks can be a result of economic regime or a change in the factors (support system or taxation, population, etc.) that determine and affect the tested series. Hence, if structural breaks are not taken into account when investigating the existence of a long-run relationship, there is a possibility that linear methods may fail to confirm the relationship when in fact it does exist.

Second, the short-run and long-run relationships between farm and retail price series are investigated. The nature of the long-run relationship is investigated applying two-step EngleGranger cointegration technique [8], because time series are integrated of order one. This approach is based on the idea that if there is a cointegration between the variables, the residuals obtained from ordinary least squares equations have to be stationary. So, in order to test for the long-run relationship between retail and farm prices, we are testing the stationarity of residuals with the help of ADF.

The Granger causality test [13] reports about the short-run relations and characterizes the direction of the farm and retail price causality along the vertical supply chain of carrots and the nature of this feedback. The Granger causality tests if one price series of carrots can be predicted by historical data of another supply chain level's price series better than by carrot prices data in the past. The Granger causality test investigates two null hypotheses $\left.\left(H_{0}\right): 1\right)$ 'Carrot retail price does not Granger cause carrot farm price'; 2) 'Carrot farm price does not Granger cause carrot retail price'. The estimation of these two $H_{0}$ will assist in setting the direction of causality and identifying the price leading stakeholder along the carrot supply chain.

The aforementioned tests have assumed that there is linearity and symmetry within the long-run relationship. However, the previous research on price transmission in carrot sector confirms that asymmetric price behaviour is often. Therefore, a momentum Threshold Autoregressive model $[9,10]$ is applied in order to ensure that asymmetries within the transmission of prices have been accounted for. The first step tests the price series for the cointegration. If cointegration is found, the next step tests for asymmetry within the 
relationship. This will identify if the price series reacts differently to an increase or decrease from the long run equilibrium or if the price behaviour is symmetric.

\section{Results and discussion}

\section{Production}

In 2016, carrots were on the top three list of the most important vegetables in the European Union (EU) [31]. Over the past seven years the EU carrot production has not demonstrated significant changes in cultivated area and harvested production. According to Eurostat [31], the main carrot producing countries were Poland (14.71\%), the United Kingdom (12.96\%), and Germany (11.48\%), while the highest shares of cultivated area were in Poland (19.17\%), France (10.87\%), and Italy (9.88\%). In 2016, Lithuania produced $0.77 \%$ of the EU carrots and the cultivated area accounted for $1.56 \%$ of the land related to the EU carrot production.

The carrot is one of the most popular vegetables grown in open fields of Lithuania. The largest share of carrots is harvested on farmer and family farms (Table 1). In 2017, the harvest of carrots on farmer and family farms accounted for $95.23 \%$ of the total harvest on all farms compared to $93.33 \%$ in 2011 [30]. Although the structure of stakeholders involved in carrot production remains stable, the changes of the main indicators of carrot production are visible.

In 2017 , the harvested area was 1,800 ha and this indicator demonstrated a decrease by $25.00 \%$ compared to 2011 [30]. According to Statistics Lithuania, the average yield on farmer and family farms is lower than at agricultural companies and enterprises. During the analysed period, the minimum and maximum average yields fluctuated from 22.69 to 33.17 tonnes per ha [30]. However, starting from the year 2015 the average yields were extremely low and reached the bottom in 2017.

Main indicators of the Lithuanian carrot production

Table 1

\begin{tabular}{|c|c|c|c|c|c|c|}
\hline & \multicolumn{2}{|c|}{$\begin{array}{c}\text { Harvest, } \\
\text { thou tonnes }\end{array}$} & \multicolumn{2}{c|}{$\begin{array}{c}\text { Average yield, } \\
\text { tonnes per ha }\end{array}$} & \multicolumn{2}{c|}{$\begin{array}{c}\text { Harvested area, } \\
\text { thou ha }\end{array}$} \\
\cline { 2 - 7 } & $\begin{array}{c}\text { Farmer and } \\
\text { family } \\
\text { farms }\end{array}$ & All farms & $\begin{array}{c}\text { Farmer and } \\
\text { family farms }\end{array}$ & All farms & $\begin{array}{c}\text { Farmer and } \\
\text { family farms }\end{array}$ & All farms \\
\hline 2011 & 65.80 & 70.50 & 28.26 & 29.32 & 2.30 & 2.40 \\
\hline 2012 & 65.30 & 67.80 & 32.14 & 32.31 & 2.00 & 2.10 \\
\hline 2013 & 54.40 & 57.50 & 25.87 & 25.99 & 2.10 & 2.20 \\
\hline 2014 & 64.90 & 68.10 & 32.74 & 33.17 & 2.00 & 2.10 \\
\hline 2015 & 39.30 & 43.80 & 22.27 & 23.57 & 1.80 & 1.90 \\
\hline 2016 & 46.20 & 49.30 & 22.64 & 23.10 & 2.00 & 2.10 \\
\hline 2017 & 39.90 & 41.90 & 22.15 & 22.69 & 1.80 & 1.80 \\
\hline 2017 & & & & & & \\
\hline compared with & 60.64 & 59.43 & 78.38 & 77.39 & 78.26 & 75.00 \\
2011 & & & & & & \\
\hline$(2011=100 \%)$ & & & & & & \\
\hline
\end{tabular}

Source: Statistics Lithuania [30], own calculations. 
Table 1 demonstrates that Lithuanian farmers have faced significant difficulties over the analysed period and the number of low harvest years dominates over the successful years. The first challenging year was 2013. After the cold, rainy spring and dry summer the average yield accounted for $80.44 \%$ of the level of 2012 . The late start of the harvesting season in many EU countries and the early shortage of the previous year harvest at Lithuanian storage houses contributed to the sharp growth of both retail and farm prices (Figure 1). However, the most challenging for farmers was the unfavourable weather period starting from 2015. The decreased carrot supply on domestic market and the growth of prices for the imported carrots determined a spike of carrot price in 2015. Although policy targeted to control the most important prices after the introduction of Euro in January 2015, the change of currency resulted in the growth of input prices and had an impact on farmers' welfare during the low harvest period. In 2016 and 2017, farm prices were not beneficial for the long-standing low harvest situation in carrot production.

It should be noted that the shrinking production of vegetables in Lithuanian agriculture was a talking-point during the national planning of the direct payment model for the period of 2014-2020. As a result, Lithuania identified this niche as experiencing difficulties and included the voluntary support, coupled to production, into the model of direct payments starting from the year 2015. The payment for field vegetables amounted to $324.2 \mathrm{EUR} / \mathrm{ha}^{2}$ in 2015, $310.9 \mathrm{EUR} / \mathrm{ha}^{2}$ in 2016, and $381.8 \mathrm{EUR} / \mathrm{ha}^{2}$ in 2017.

During the analysed period, additional policy interventions were made to support communication and sales at vegetable market, promote consumption of vegetables at preschool institutions and primary classes. The stabilization of supply and price on the carrot market after the Russian ban was ensured introducing support for market withdrawals and harvesting measures. This type of support remained relevant for carrot producers even in 2017. However, the changes of the harvested area for the period 2015-2017 show that unfavourable weather conditions and reduced margins were more important arguments than policy interventions.

\section{Foreign trade}

Another important driving force encouraging or discouraging to develop carrot production could be the situation on the market, i. e. both export/import situation and market efficiency problems in the domestic supply chain. The comparisons of import, re-export, and export indicators during the period of 2011-2017 evidence the important changes of the foreign trade situation (Figure 2). The analysis of the foreign trade situation is conducted using the aggregated indicator of carrots and turnips ( $\mathrm{CN}$ code: 07061000$)$. It is important to note that the production of turnips is not significant and the aggregated indicator could be used to monitor changes on the carrot market.

The impressive decrease of import from 2016 is explained by a significant decline of reexport to Russia and Belarus. To be more specific, the drastic changes in the structure of export and import were aftermaths of the response to the EU sanctions over the Ukraine crisis. In August 2014, Russia imposed an import ban on a list of agricultural commodities of the EU origin, and trade restrictions included the vegetable sector. As a result, during the analysed period, export and re-export of carrots and turnips reduced twice, and Lithuanian producers of carrots switched the trade from third countries to the EU market (Table 2). 


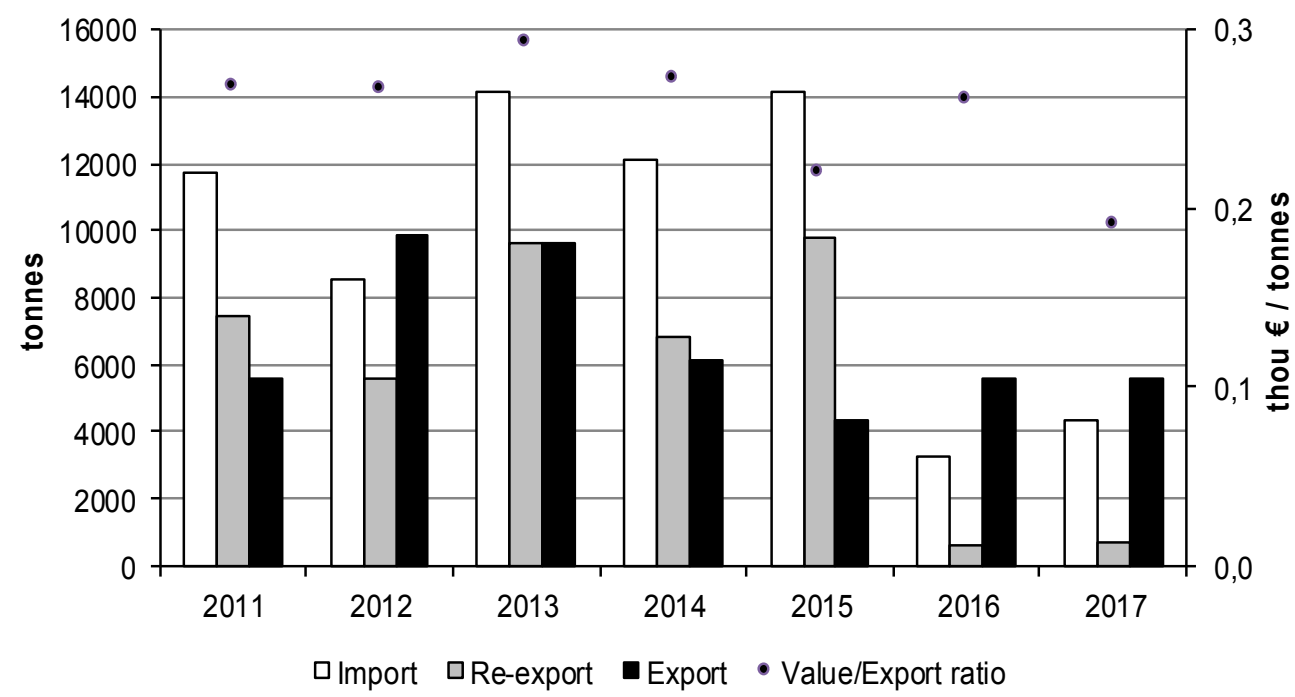

Figure 2. Developments of export, re-export, and import of carrots and turnips in 2011-2017 Source: Statistics Lithuania [32], own calculations.

During the analysed period, the share of third countries in the structure of export dropped from 92.10 to $7.77 \%$. The structure of Lithuanian carrot export became more diversified, and the Baltic countries occupied the position of main trading partners. Although the decrease of the total amount of exported carrots and turnips was dramatic, the amount of the exported domestic carrots and turnips had increased and was slightly higher than the level of 2011.

However, the comparison of the annual indicator of value per tonne over the period of 2011-2017 shows that access to the market of third countries allowed to ensure higher and more stable indicator for domestic carrots and turnips until the period of import ban (Figure 2). The changes in the structure of foreign trade reduced the annual indicator of value per tonne and had an impact on farmers' welfare.

\section{Domestic supply chain}

Resuming the results for the period of 2011-2017, the development of carrot production in Lithuania was heavily dependent on weather conditions and trade restrictions. However, market inefficiency issues related to price changes along the supply chain of carrots could be an important contributor to the shrinking of domestic carrot production too. In order to identify market development problems the nature of the long-run and short-run relations between farm and retail prices of carrots is investigated.

First, the unit root test is conducted. The results of ADF test at level show that for both farm and retail prices absolute values of $t$-statistic is lower than critical values at $5.00 \%$ significance level (Table 3). Thus, the $H_{0}$ that data series contain a unit root cannot be rejected. However, ADF tests at first differences show that the $H_{0}$ could be rejected. 
Structure of carrot and turnip export in 2011-2017

\begin{tabular}{|c|c|c|}
\hline Year & Export structure by country $(\%)$ & $\begin{array}{l}\text { Total amount } \\
\text { of exported } \\
\text { carrots and } \\
\text { turnips, tonnes }\end{array}$ \\
\hline 2011 & 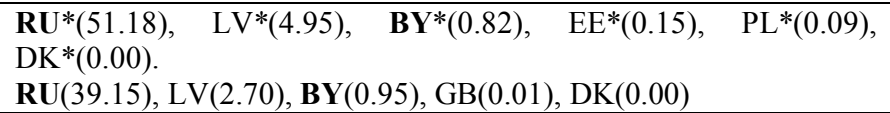 & $13,002.80$ \\
\hline 2012 & 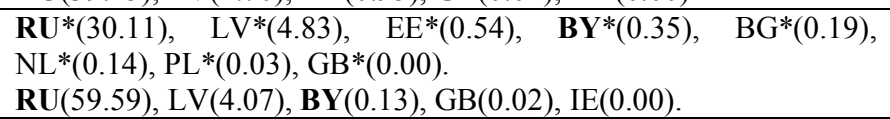 & $15,430.13$ \\
\hline 2013 & 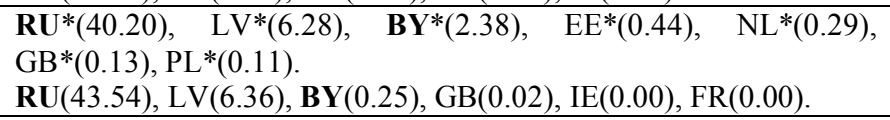 & $19,269.66$ \\
\hline 2014 & $\begin{array}{l}\mathbf{R U}^{*}(28.50), \quad \mathbf{B Y}^{*}(21.04), \quad \mathrm{LV}^{*}(1.81), \quad \mathrm{EE}^{*}(0.95), \\
\mathrm{NL}^{*}(0.05), \mathbf{M} \mathbf{K}^{*}(0.01), \mathbf{A F}(0.07), \\
\mathbf{R U}(33.94), \mathrm{LV}(11.41), \mathbf{B Y}(2.07), \mathbf{K Z}(0.10), \mathrm{GB}(0.04), \mathrm{IE}(0.00)\end{array}$ & $12,973.89$ \\
\hline 2015 & 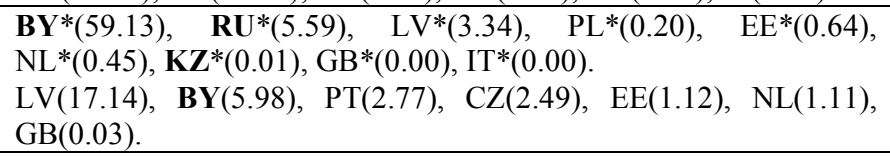 & $14,144.94$ \\
\hline 2016 & $\begin{array}{l}\mathrm{GB}^{*}(4.22), \quad \mathbf{B Y} *(2.83), \quad \mathrm{LV}^{*}(2.56), \quad \mathbf{R U}^{*}(0.55), \\
\mathrm{KZ}^{*}(0.02), \mathrm{IT}^{*}(0.02), \mathrm{PL}(0.24), \\
\mathrm{LV}(66.87), \mathrm{EE}(14.54), \mathbf{B Y}(5.55), \mathrm{ES}(0.00) . \\
\mathbf{K Z}(0.04), \operatorname{DK}(0.01), \mathbf{A F}(0.04), \mathrm{BG}(0.00) .\end{array}$ & $6,259.17$ \\
\hline 2017 & $\begin{array}{l}\mathbf{B Y}^{*}(6.38), \mathrm{LV}^{*}(3.55), \mathrm{EE}^{*}(0.38), \mathrm{PL}^{*}(0.13), \mathrm{IT}^{*}(0.06), \mathbf{R U}^{*}(0.03), \\
\mathrm{GB}^{*}(0.00), \\
\mathrm{LV}(62.58), \mathrm{EE}(24.35), \mathbf{B Y}(1.34), \mathrm{NL}(0.67), \mathrm{GB}(0.49), \mathbf{K Z}(0.02), \\
\operatorname{DK}(0.02), \operatorname{PL}(0.00), \mathrm{FI}(0.00)\end{array}$ & $6,290.05$ \\
\hline
\end{tabular}

The asterisk refers to re-export of carrots and turnips. Bold font signifies export of carrots and turnips to third countries. ISO standard is applied to code countries.

Source: own calculations on the basis of the data collected by Statistics Lithuania [32].

ADF unit root test results for the retail and farm carrot prices

Table 3

\begin{tabular}{|c|c|c|c|c|}
\hline \multicolumn{2}{|c|}{ Variables } & $\begin{array}{l}\text { ADF } t- \\
\text { statistic }\end{array}$ & $\begin{array}{c}\text { Test critical value } \\
\text { at } 5.00 \% \\
\text { significance level }\end{array}$ & $\begin{array}{l}\text { MacKinnon (1996) } \\
\text { one-sided } p \text {-values }\end{array}$ \\
\hline \multicolumn{2}{|l|}{ Farm price $(0)$} & 0.09 & -1.95 & 0.71 \\
\hline \multicolumn{2}{|l|}{ Retail price (2) } & -1.05 & -1.95 & 0.26 \\
\hline \multicolumn{2}{|l|}{$\mathrm{D}$ (Retail price (1))* } & -5.13 & -1.95 & 0.00 \\
\hline \multicolumn{2}{|l|}{$\mathrm{D}(\text { Farm price }(1))^{*}$} & -3.97 & -3.47 & 0.01 \\
\hline \multicolumn{5}{|c|}{ Unit root with single break } \\
\hline Variables & Break date & $\underset{t \text {-statistic }}{\text { ADF }}$ & $\begin{array}{c}\text { Test critical value } \\
\text { at } 1.00 \% \\
\text { significance level }\end{array}$ & $\begin{array}{c}\text { Vogelsang (1993) } \\
\text { asymptotic one-sided } \\
p \text {-values }\end{array}$ \\
\hline $\mathrm{D}(\text { Farm price }(0))^{*}$ & 2012M05 & -6.60 & -4.95 & $<0.01$ \\
\hline $\mathrm{D}(\text { Retail price }(1))^{*}$ & 2015M04 & -5.96 & -4.95 & $<0.01$ \\
\hline
\end{tabular}

The lag length (based on Schwarz Information Criterion, maxlag =11) for the price series is provided in parentheses. ${ }^{*}$ means that $H_{0}$ can be rejected. [Source: own calculations]. 
The similar results of price stationarity at first difference were found for carrots on markets in the USA [6, 15], while in the United Kingdom [17], Germany [17], and Hungary [3] price series were stationary. The study of Austrian market showed that producer prices were stationary, but retail prices were stationary only at first difference.

The ADF test with single break shows that in case of both farm and retail prices at first difference the break dates, significant at $1.00 \%$ level, could be identified. Farm price series show break date in May 2012, while the break in retail prices is dated by April 2015. The latter break could be related to the aftermaths of the Russian ban and changes in export structure as this market closed alternative routings gradually. The situation also could be explained by the introduction of Euro as the German study of structural breaks in retail price series of carrots and cucumbers witnesses the similar behaviour [12].

Engle-Granger two-steps technique for price series including breaks in 2012 and 2015 is conducted in order to identify the nature of the long-run relations between prices. However, the coefficient for 2012 break is not significant. The results of Engle-Granger test with the single break in 2015 are provided in Table 4 . The first step shows that derived coefficients are significant at $1.00 \%$ level.

Results of the Engle-Granger technique (1st step)

Table 4

\begin{tabular}{|c|c|c|c|c|}
\hline & Coefficient & $t$-statistic & Std. Error & Prob. \\
\hline Retail price & 0.71 & 12.20 & 0.06 & 0.00 \\
\hline D2015 & 0.19 & 4.43 & 0.04 & 0.00 \\
\hline Constant & -1.17 & -20.99 & 0.06 & 0.00 \\
\hline$R$-squared & 0.67 & \multicolumn{2}{|c|}{ Durbin-Watson } & 0.65 \\
\hline Adjusted $R$-squared & 0.66 & \multicolumn{2}{|l|}{$F$-statistic } & 75.76 \\
\hline
\end{tabular}

Source: own calculations.

The testing of the residuals for the presence of a unit root is the second step of the EngleGranger unit root test. The results report that we can reject the $H_{0}$ that there is a unit root for the tested period, because the computed absolute $t$-statistic value for the first period (-7.65) is higher than the critical value (-4.11). We conclude that the residuals are stationary as the $H_{0}$ could be rejected at $1.00 \%$ significance level. As a result, the derived equation is a cointegrated and non-spurious regression. The results of Engle-Granger test prove the evidence of the long-run relationship between carrot prices on farm and retail levels.

The next step is to analyse the causality and feedback. The Granger causality test refers to the short-run relations between the analysed price series. The test empowers answering the question 'Do changes in retail price series of carrots cause changes in farm price series of carrots, and vice versa?' and setting the direction of these causalities (Table 5). If lagged farm prices explain the retail prices, and vice versa, the conclusions on the leading role of farmers or retailers could be made. However, this test does not help to predict future movements of variables [5].

The first $H_{0}$ 'Carrot retail price does not Granger cause carrot farm price' can be rejected at $5.00 \%$ significance level, and retail prices do lead farm prices of carrots in the short run. The second $H_{0}$ 'Carrot farm price does not Granger cause carrot retail price' cannot be rejected, and farm prices do not lead retail prices in the short run. 
Results of Granger causality test for carrot prices

\begin{tabular}{|c|c|c|}
\hline $\boldsymbol{H}_{0}$ & F-Statistic & Prob. \\
\hline Carrot retail price does not Granger cause carrot farm price & $4.15^{*}$ & 0.02 \\
\hline Carrot farm price does not Granger cause carrot retail price & 1.47 & 0.24 \\
\hline
\end{tabular}

Lags: $2 / / *$ indicate rejection of the $H_{0}$ at the $5.00 \%$ level of significance.

Source: own calculations.

According to the findings of the previous research $[3,17,27]$, the situation in the Lithuanian carrot market is not typical and this commodity could demonstrate both onedirection and bi-directional causality, while the leading stakeholder could differ from country to country. It should be noted that important causality links could be found even outside the supply chain of the commodity. For example, the study of the relationship between prices of organic and conventional carrots in the USA argues that organic market Granger cause price level of conventional carrots [15].

Finally, we test the selected price series for asymmetry applying Threshold Autoregressive Model. The residuals obtained from the Engle-Granger procedure were decomposed and tested for cointegration and asymmetry. The results of the estimation are provided in Table 6.

Table 6

Threshold Autoregressive Model for carrot prices

\begin{tabular}{|l|c|c|}
\hline & Coefficient & Std. Error \\
\hline Above threshold & -0.47 & 0.12 \\
\hline Below threshold & -0.15 & 0.15 \\
\hline \multicolumn{2}{|c|}{} \\
\hline Threshold Value & 0.00 & $(3.52)^{*}$ \\
\hline$F$-equal & 2.98 & $(-1.65)^{*}$ \\
\hline$T$-max value & -1.00 & $(4.70)^{*}$ \\
\hline$F$-joint (phi) & 7.55 & \\
\hline
\end{tabular}

* Simulated critical values for $5.00 \%$ significance level.

Source: own calculations.

The comparision of $F$-joint with critical value suggests that there is a cointegration between farm and retail prices. However, $F$-joint is higher than critical value and the $H_{0}$ of asymmetry is rejected. Thus, positive and negative shocks from retailer prices affected farmer prices in the same magnitude, and the results do not confirm related market inefficiency problems.

Although the results of the conducted study witness in favour of the symmetry, the nature of the asymmetric price behaviour in vegetable markets is widely discussed [23, 24, 27]. Even research with a specific focus on carrot market [17, 23, 24, 27] provides an evidence of both symmetric and asymmetric price transmission in the long run. Thus, it is important to mention that the introduction of the more detailed stakeholders' analysis could have an impact on findings in the Lithuanian carrot market. 


\section{Conclusion}

The analysis of the main indicators of carrot production for the period from 2011 to 2017 shows that the harvested area declined by $1 / 4$, while the reduction of harvest was even higher than by $1 / 3$. During the analysed period, the important factors determining farmers' welfare and contributing to the shrinking of carrot production were weather conditions and the import ban for vegetables imposed by Russia.

The introduction of trade ban in 2014 negatively affected farmers' welfare and dramatically changed the structure of foreign trade by carrots in Lithuania. The study allows to state that national policy should encourage the diversification of export structure in the individual sectors of agriculture in order to avoid dependence on trading partners with the dominant share of the market. The absence of this strategy leads to the imminent losses of welfare for farmers and could be an expensive burden for taxpayers in case if the dominant partner impose trade restrictions.

The analysis of the Granger causality in domestic carrot supply chain shows that in the short-run retailers lead carrot price and have an impact on farmers' welfare situation, while causality runs from the retail prices to the farm prices. This result shows that retailers may exercise some market power and could influence the level of farm prices. The research results confirm the presence of the long-run relationship between farm and retail prices. Finally, there is a strong evidence of symmetric price behaviour along the carrot chain, i. e. positive and negative shocks are transmitted from retailers to farmers, and vice versa, with the same intensity.

\section{References}

1. Ahmed O. (2018), Vertical Price Transmission in Egyptian Tomato Sector after the Arab Spring, Applied Economics, pp. 1-16.

2. Aquiar D.R.D., Santana J.A. (2002), Asymmetry in Farm to Retail Price Transmission: Evidence from Brazil, Agribusiness, 18(1), pp. 37-48.

3. Bakucs Z., Fałkowski J., Fertö I. (2013), What causes asymmetric price transmission in agro-food sector? Meta-analysis perspective, Discussion Paper No MT-DP - 2013/3, Institute of Economics, Research Centre for Economic and Regional Studies, Hungarian Academy of Sciences, $23 \mathrm{p}$.

4. Bakucs L.Z., Fertö I., Szabó G.G. (2007), Price transmission in the Hungarian vegetable sector, Studies in Agricultural Economics, 106, pp. 23-40.

5. Brooks C. (2008), Introductory Econometrics for Finance, Cambridge, Cambridge University Press.

6. Darbandi E., Saghaian S. (2016), An Empirical Comparison of Price Transmission between Conventional and Organic Products: The Case of Fresh Carrots, 2016 Annual Meeting, February 6-9, 2016, San Antonio, Texas, available at: https://ideas.repec.org/p/ags/saea16/230124.html.

7. Dickey D.A., Fuller W.A. (1979), Distribution of the Estimators for Autoregressive Time Series with a Unit Root, Journal of the American Statistical Association, 74(366), pp. 427-431.

8. Engle, R.F.; Granger, C.W.J. (1987), Co-integration and error correction: Representation, estimation and testing, Econometrica, 55(2), pp. 251-276. 
9. Enders, W., \& Granger, C.W.J. (1998), Unit-Root Tests and Asymmetric Adjustment with an Example Using the Term Structure of Interest Rates, Journal of Business \& Economic Statistics, 16(3), pp. 304-311.

10. Enders, W., \& Siklos, P.L. (2001), Cointegration and Threshold Adjustment, Journal of Business \& Economic Statistics, 19(2), pp. 166-176.

11. Gardner B.L. (1975), The Farm-Retail Price Spread in a Competitive Food Industry, American Journal of Agricultural Economics, August, pp. 399-409.

12. Glauben T., Loy J.P., Meyer J. (2005), The impact of Euro introduction on the vertical price transmission in the German food market - Does money illusion matter? $X I^{\text {th }}$ Congress the EAAE, 'The Future of Rural Europe in the Global Agri-Food System', Copenhagen, Denmark, August 24-27, 2005.

13. Granger C.W.J. (1969), Investigating Causal Relations by Econometric Models and Cross-spectral Methods, Econometrica, 37(3), pp. 424-438.

14. Jeder H., Naimi A., Oueslati A. (2017), Transmission between Retail and Producer Prices for Main Vegetable Crops in Lithuania, International Journal of Food and Agricultural Economics, 5(1), pp. 19-28.

15. Kim G., Seok J.H., Mark T.B., Reed M.R. (2018), The price relationship between organic and non-organic vegetables in the U.S.: evidence from Nielsen scanner data, Applied Economics, pp. 1-15.

16. Li C., Sexton R.J. (2013), Grocery-Retailer Pricing Behavior with Implications for Farmer Welfare, Journal of Agricultural and Resource Economics, 38(2), pp. 141-158.

17. London Economics. (2004), Investigation of the determinants of farm-retail price spreads: final report to DEFRA, London Economics.

18. Maître d'Hôtel E., Le Cotty T. (2018), Why does on-farm storage fail to mitigate price volatility? Agricultural Economics, 49(2018), pp. 71-82.

19. Napaporn G., VanSickle J.J., Renwick A. (2003), Price Asymmetry in the United States Fresh Tomato Market, Journal of Food Distribution Research, 34(3), pp. 1-9.

20. Parrot S.D., Eastwood D.B., Brooker J.R. (2001), Testing for Symmetry in Price Transmission: An Extension of the Shiller Lag Structure with an Application to Fresh Tomatoes, Journal of Agribusiness, 19(1), pp. 35-49.

21. Pérez Mesa J.C., Galdeano Gómez E. (2011). Asymmetric Margines in Prices and retail Supply Chain Integration: The Spanish Vegetable Case, Journal of International Food and Agribusiness Marketing, 23, pp. 211-230.

22. Santeramo F.G., Cioffi A. (2012), Transmission of Market Crises in the European Vegetable Sector, PAGRI, 2(2012), pp. 37-46.

23. Santeramo F.G., Gioia L.D. (2018), A Review of Supply Chain Prices Analyses with Emphasis on Perishable Markets, in Agricultural Value Chain, IntechOpen, London.

24. Santeramo F.G., von Cramon-Taubadel S. (2016), On Perishability and Vertical Price Transmission: Empirical Evidence from Italy, Bio-based and Applied Economics, 5(2), pp. 199-214.

25. Verreth D.M.I., Emvalomatis G., Bunte F., Kemp R., Oude Lansink A.G.J.M. (2015), Price Transmission, International Trade, and Asymmetric Relationships in the Dutch Agri-Food Chain, Agribusiness, 31(4), pp. 521-542.

26. Von Cramon-Taubadel S. (2017), The analysis of market integration and price transmission - results and implications in an African context, Agrekon, 56(2), pp. 8396.

27. Ward R.W. (1982), Asymmetry in Retail, Wholesale, and Shipping Point Pricing for Fresh Vegetables, American Journal of Agricultural Economics, May, pp. 205-212. 
28. Xie H., Wang B. (2017), An Empirical Analysis of the Impact of Agricultural Product Price Fluctuations on China's Grain Yield, Sustainability, 9, 906, pp. 1-14.

29. Zainalabidin M., Iliyasu A. (2017), Analysis of Asymmetric Price Transmission of Selected Vegetables in Peninsular Malaysia, Malaysian Journal of Mathematical Sciences, 11(S) February, 87-100.

30. (2018), Agriculture, Crop Production, available at: https://osp.stat.gov.lt/statistiniurodikliu-analize?theme $=$ all $\# /$.

31. (2018), Crop production in national humidity, available at: http://appsso.eurostat.ec.europa.eu/nui/show.do?dataset=apro_cpnh1\&lang=en.

32. (2018), Foreign Trade, Detailed foreign trade indicators, available at: https://osp.stat.gov.lt/statistiniu-rodikliu-analize\#/. 